\title{
RANCANG BANGUN MENARA REFLUKS PADA DESTILATOR BIOETHANOL KAPASITAS 5 LITER/JAM BERSKALA UMKM
}

\author{
Hendri Susanto \\ Fakultas Teknik, Program Studi Teknik Mesin \\ Universitas Muria Kudus \\ Email: 201454074@std.umk.ac.id \\ Rochmad Winarso \\ Fakultas Teknik, Program Studi Teknik Mesin \\ Universitas Muria Kudus \\ Email: rochmad.winarso@umk.ac.id \\ Rianto Wibowo \\ Fakultas Teknik, Program Studi Teknik Mesin \\ Universitas Muria Kudus \\ Email: rianto.wibowo@umk.ac.id
}

\begin{abstract}
ABSTRAK
Bioethanol merupakan energi terbarukan yang berasal dari bahan dasar nabati. Sebagaimana fungsinya, bioethanol diharuskan memiliki tingkat kemurnian sesuai dengan standar mutu yang telah ditentukan sebagai energi terbarukan. Untuk mencapai keketentuan tersebut, telah dilakukan proses rancang bangun menara refluks pada destilator bioethanol pada saat proses kondensasi berlangsung. Metode yang digunakan pada penelitian ini adalah berupa studi literatur terhadap artikel terkait, proses perencanaan design, perancangan dan pembuatan terhadap komponen komponen penyusun dari menara refluks, serta proses pengujian mesin untuk mengetahui fungsi kerja dari menara refluks pada destilator bioethanol. hasil penelitian menunjukkan menara refluks dapat digunakan sebagai proses kondensasi pada siklus destilasi bioethanol. Dengan dimensi shell berdiameter $114 \mathrm{~mm}$ dan tinggi $2000 \mathrm{~mm}$, dimensi tube berdiameter $94 \mathrm{~mm}$ dan tinggi total coil $400 \mathrm{~mm}$ dengan jarak antar coil $40 \mathrm{~mm}$. dan dihasilkan kapasitas produksi ethanol pada mesin destilator bioethanol seabnyak 2,35 liter dengan kadar kemurnian 91\%.
\end{abstract}

Kata kunci : bioethanol, kondensasi, menara refluks, kemurnian

\begin{abstract}
Bioethanol is a renewable energy derived from vegetable base material. As a functions, bioethanol is required to have a degree of purity in accordance with quality standards that have been determined as renewable energy. To achieve this regulation, a reflux tower design process has been built on bioethanol destilator in order to increase the purity level of bioethanol during the condensation process. The method used in this research is literature study on related articles, design planning process, designing and manufacturing components of the reflux tower, and testing process of the machine to recognize the working function of the reflux tower on bioethanol destilator. The results showed that the reflux tower can be used as a condensation process in the distillation cycle of bioethanol. With shell dimensions $114 \mathrm{~mm}$ in diameter and $2000 \mathrm{~mm}$ in height, tube dimensions $94 \mathrm{~mm}$ in diameter and $400 \mathrm{~mm}$ total coil height with pitch distance of $40 \mathrm{~mm}$ coil. And the production capacity of ethanol is 2,35 liters with the highest purity level of $91 \%$.
\end{abstract}

Keywords : bioethanol, condensation, reflux tower, purity 


\section{PENDAHULUAN}

Kebutuhan energi dari bahan bakar minyak bumi (BBM) di berbagai negara di dunia dalam tahun terakhir ini mengalami peningkatan. Tidak hanya pada negara - negara maju, tetapi juga di negara berkembang seperti Indonesia. Untuk mengantisipasi krisis bahan bakar minyak bumi (BBM) pada masa yang akan datang. Saat ini telah dikembangkan pemanfaatan etanol sebagai sumber energi terbarukan, contohnya untuk pembuatan bioethanol.

Bioetanol $\left(\mathrm{C}_{2} \mathrm{H}_{5} \mathrm{OH}\right)$ merupakan salah satu biofuel yang hadir sebagai bahan bakar alternatif yang ramah lingkungan dan sifatnya yang terbarukan. Bioetanol dapat diproduksi dari berbagai bahan baku yang banyak terdapat di Indonesia, sehingga sangat potensial untuk diolah dan dikembangkan karena bahan bakunya sangat dikenal masyarakat. Tumbuhan yang potensial untuk menghasilkan bioetanol antara lain tanaman yang memiliki kadar karbohidrat tinggi, seperti : tebu, nira, aren, sorgum, ubi kayu, jambu mete (limbah jambu mete), garut, batang pisang, ubi jalar, jagung, bonggol jagung, jerami dan bagas [1].

Sedangkan menurut [2] bioetanol merupakan etanol yang terbuat dari hasil fermentasi tanaman yang mengandung karbohidrat dengan bantuan mikroorganisme. Bioetanol dikembangkan sebagai bahan bakar pengganti BBM dengan fuel grade ethanol $\geq 99,5 \%$ untuk mengimbangi kelangkaan sumber minyak bumi. Bioetanol menjadi energi alternatif karena memiliki kandungan oksigen yang tinggi, bilangan oktan yang tinggi, mudah terurai, dan sumber energi di perbaharui. Kandungan oksigen yang tinggi akan meningkatkan efisiensi pembakaran dan mengurangi terjadinya pencemaran akibat gas buang seperti emisi hidrokarbon, karbon monoksida, dan emisi partikulat, ataupun gas - gas rumah kaca. Bioethanol sebagai energi alternatif sangatlah berpengaruh terhadap tingkat kemurnian yang dimiliki. Dimana dalam pencapaian tingkat kemurnian tersebut, akan dikembangkan alat untuk proses pengolahan bioethanol dengan tingkat kemurnian tinggi, yaitu dengan menggunakan destilator bioethanol sistem reflux bertingkat.

Karakteristik etanol sebagai bahan bakar memiliki nilai kerapatan massa $780\left(\mathrm{~kg} / \mathrm{m}^{3}\right)\left(20^{\circ} \mathrm{C}\right)$ dan kalor pembakaran $9600(\mathrm{Kcal} / \mathrm{kg})$. Selain itu bioethanol juga memiliki banyak sifat - sifat fisika maupun kimia [3]. Berikut pada tabel 1 merupakan karakteristik sifat fisika pada etanol

Tabel 1. Sifat fisika etanol

\begin{tabular}{clc}
\hline No. & Sifat Fisika Etanol & Keterangan \\
\hline 1. & Berat Molekul & $46,06 \mathrm{gr} / \mathrm{mol}$ \\
2. & Titik Molekul & $78,4^{\circ} \mathrm{C}$ \\
3. & Densitas & $0,7893 \mathrm{gr} / \mathrm{mL}$ \\
4. & Indesk Bias & $1,36143 \mathrm{cP}$ \\
5. & Viskositas $20^{\circ} \mathrm{C}$ & $1,17 \mathrm{cP}$ \\
6. & Panas Penguapan & $200,6 \mathrm{kal} / \mathrm{gr}$ \\
7. & Warna Cairan & Tidak Berwarna \\
8. & Kelarutan & Larut Dalam Air \\
9. & Aroma & Memiliki Aroma Yang Khas \\
\hline
\end{tabular}

Berdasarkan karakteristik serta manfaat bioethanol terhadap supply energi, maka akan dilakukan proses rancang bangun pada komponen destilator bioethanol yaitu menara refluks. Dimana proses rancang bangun ini ditujukan untuk meningkatkan kadar kemurian bioethanol sebagai energi terbarukan.

Dengan mengendalikan temperatur pendingin, sering disebut sebagai deflegmator, sebuah reflux steel dapat digunakan untuk memastikan bahwa komponen yang mempunyai titik didih lebih tinggi kembali ke dalam labu sementara unsur - unsur yang lebih ringan keluar menuju pendingin kedua.

Dalam proses pelaksanaannya, metode ekstraksi dengan menggunakan sistem refluks ini sangatlah sederhana, sehingga mempercepat kerja yang dilakukan, suhu yang digunakan sesuai 
dengan pelarut yang digunakan dan sangat cocok digunakan untuk mengekstraksi sampel yang mempunyai tekstur keras dan komponen kimianya tahan terhadap pemanasan, serta dengan menggunakan metode ini maka proses ekstraksi dapat dilakukan dalam waktu yang relatif lebih singkat [4].

Adanya pengaruh perlakuan panas pada refluks dapat meningkatkan kemampuan pelarut untuk mengekstraksi senyawa - senyawa yang tidak larut di dalam kondisi suhu kamar, sehingga aktivitas penarikan senyawa lebih maksimal atau memberikan peningkatan rendemen [5].

Cara kerjanya adalah, uap panas alcohol dan air yang naik akan menyentuh reflux coil. Karena reflux coil lebih dingin (akibat aliran air) dari pada uap alcohol - air, maka uap akan terkondensasi atau menjadi cair lagi dan jatuh ke packing. Dalam perjalanan jatuhnya cairan tersebut di dalam kolom akan bertemu dengan uap panas dari bawah yang naik sehingga cairan menjadi panas kembali dan alcohol menguap dengan kandungan yang lebih kaya karena alcohol bertitik didih lebih rendah dari pada air, sementara itu air akan terus turun sampai mendapatkan panas yang cukup untuk menguap lagi. Proses ini terjadi berulang ulang didalam kolom sampai akhirnya sebagian uap berhasil lolos menuju kondensor. Uap yang lolos ini sudah berkadar alcohol tinggi karena sudah beberapa kali mengalami proses naik-turun atau destilasi berulang kali didalam kolom [6].

Secara garis besar, komponen utama dari menara refluks adalah dengan menggunakan baja tahan karat atau stainless steel. Dimana tujuan dari penggunaan baja tahan karat ini adalah dari sifatnya yang tahan karat dan tahan terhadap suhu kerja yang tinggi.

Dilaporkan pada bahwa, berdasarkan hasil uji coba yang telah dilakukan menggunakan bahan fermetasi ketela pohon dengan proses fermentasi selama 46 jam, didapat kadar etanol tertinggi sebesar 76\% [7].

Proses penelitian tersebut berlanjut dalam proses pengembangan destilator bioethanol model refluks, dan dari hasil uji coba pada proses destilasi fermentasi ketela pohon menunjukkan kadar tertinggi yang dapat dihasilkan dari mesin destilasi bioethanol dengan sistem refluk bertingkat adalah $92 \%[8]$.

\section{METODOLOGI}

Penelitian ini dilakukan melalui tiga tahapan utama, yaitu : (1) Tahap perancangan atau design menara refluks pada destilator bioethanol; (2) Tahap pembuatan menara refluks berdasarkan spesifikasi, dan dimensi yang telah ditentukan; (3) Tahap pengujian menara refluks yang berorientasikan pada hasil capaian yang diharapkan, serta pengujian pada mesin destilator bioethanol yang telah dilakukan proses perancangan dan pembuatan.

Tahap satu yaitu proses perancangan design menara refluks, dilakukan kegiatan sebagai berikut: proses design yang meliputi design bentuk dan dimensi dari masing - masing komponen menara refluks. Serta proses pemilihan material bahan yang akan digunakan. Tahap dua yaitu proses pembuatan menara refluks yang terdiri atas komponen - komponen yaitu flange, sekat zeolit, reflux coil, pipa refluks, dan menara pendingin. Proses pemesinan yang digunakan dalam pembuatan menara refluks ini meliputi pemotongan, pengeboran, pengerollan, dan pengelasan. Tahap ketiga yaitu pengujian menara refluks yang berorientasikan hasil dari proses heat transfer yang dilakukan dengan capaian suhu $78^{\circ} \mathrm{C}$. Proses pengujian berikutnya adalah pada mesin destilator bioethanol yang berorientasikan pada hasil capaian 5 liter/jam dengan tingkat kemurnian diatas $90 \%$. Berikut pada gambar 1, merupakan design perencanaan menara refluks pada destilator bioethanol. 


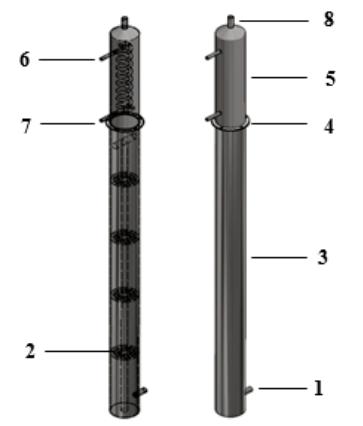

Gambar 1. Menara Refluks

Keterangan gambar :

1. Saluran masuk uap etanol

2. Sekat zeolit

3. Menara penndingin

4. Flange

5. Pipa refluks

6. Saluran masuk air pendingin

7. Saluran keluar air pendingin

8. Saluran keluar uap etanol

Sistem kerja dari menara refluks pada desitilator bioethanol ini pada umumnya adalah sebagai berikut :

1. Bahan fermentasi yang telah dipanaskan pada tangki pemanas akan terjadi fase penguapan, selanjutnya uap yang terbentuk akan mengalir menuju ke menara refluks melalui pipa penghubung.

2. Didalam menara refluks uap akan melewati kolom bertingkat yang berisi batu zeolit. Batu tersebut berfungsi untuk menangkap uap air panas sehingga kadar air dapat berkurang dalam proses destilasi, dan proses tersebut berulang - ulang sebanyak 4 kali didalam kolom destilasi.

3. Selanjutnya uap akan menuju ke reflux coil untuk pendinginan awal. Karena reflux coil bertemperatur lebih dingin (akibat aliran air) daripada uap alkohol - air, maka uap tersebut akan mengalami proses kondensasi sehingga menjadi cair lagi dan akan jatuh ke bawah. Dalam perjalanan jatuhnya cairan tersebut, di dalam kolom akan bertemu dengan aliran uap panas dari bawah yang naik ke atas, sehingga cairan akan menjadi panas kembali. Alkohol akan menguap dengan kandungan yang lebih kaya karena alkohol bertitik didih lebih rendah daripada air, sementara itu air akan terus turun sampai mendapatkan panas yang cukup untuk menguap kembali.

4. Kemudian uap etanol akan mengalir ke sistem kondensor (sistem pendinginan uap) sehingga akan menjadi cairan ethanol.

\section{HASIL DAN PEMBAHASAN}

Pada proses perencanaan menara refluks pada destilator ini meliputi, perhitungan perancangan, simulasi design, perhitungan pembuatan dan proses pengujian.

\subsection{Perhitungan perancangan menara refluks}

Perhitungan proses perancangan yang dilakukan pada penelitian rancang bangun menara refluks pada destilator bioethanol ini meliputi : 
1. Perhitungan bejana tekan

Data awal perhitungan yang ditetapkan meliputi tekanan dalam bejana (p) $500.000 \mathrm{~N} / \mathrm{m}^{2}$ dengan safety factor 2.5, diameter bejana (D) $114 \mathrm{~mm}$, panjang (L) $2000 \mathrm{~mm}$ dan tebal (t) $2 \mathrm{~mm}$ dengan tegangan tarik ijin bahan $205 \times 10^{6} \mathrm{~N} / \mathrm{m}^{2}$.

Perhitungan bejana tekan [9] yang dilakukan bertujuan untuk mengetahui kemampuan bejana dalam sistem kerjanya, yang meliputi :

2. Analisa ketebalan bejana terhadap kemungkinan belah (tb) dan kemungkinan putus (tp)

Analisa ketebalan bejana terhadap kemungkinan belah dapat dihitung menggunakan persamaan 1 berikut :

$t_{b}=\frac{D \cdot p}{2 \cdot \sigma_{t}\left(\frac{D}{L}\right)}$

Ketebalan bejana terhadap kemungkinan putus dihitung menggunakan persamaan 2 berikut :

$\mathrm{t}_{\mathrm{p}}=\frac{\mathrm{p} \cdot \mathrm{D}}{4 \cdot \sigma_{\mathrm{t}}}$

Berdasarkan proses perhitungan analisa ketebalan bejana didapatkan data hasil perhitungan sebagaimana tabel 2 berikut:

Tabel 2. Data hasil perhitungan

\begin{tabular}{ccc}
\hline Variabel Perhitungan & $\begin{array}{c}\text { Hasil } \\
(\mathbf{m m})\end{array}$ & Ketentuan \\
\hline tb & 0.33 & $\mathrm{t}_{\mathrm{b}} \geq \mathrm{t}_{\mathrm{p}}$ \\
$\mathrm{tp}$ & 0.17 & \\
\hline
\end{tabular}

3. Analisa gaya pada bejana terhadap kemungkinan belah dan kemungkinan putus

Gaya yang membelah dinding bejana pada menara refluks dapat dihitung menggunakan persamaan 3 berikut :

$\mathrm{P}=\mathrm{L} \cdot \mathrm{D} \cdot \mathrm{p}$

Gaya sebesar $(\mathrm{P})$ ditahan oleh dinding bejana dengan luas irisan $\left(\mathrm{A}_{1}\right)$, sebagaimana persamaan 4 .

$A_{1}=\{2 \cdot L \cdot t+2 \cdot t(D+2 t)\}$

Dengan terjadi tegangan didalam bejana tekan tekan sebesar $\sigma \mathrm{t}$, sebagaiman persamaan 5 .

$\sigma \mathrm{t}=\frac{\mathrm{P}}{\mathrm{A}_{1}}$

Gaya yang memutuskan dinding bejana pada menara refluks dapat dihitung menggunakan persamaan 6 berikut :

$\mathrm{P}=\frac{\pi}{4} \mathrm{D}^{2} \cdot \mathrm{p}$ 
Gaya sebesar (P) akan ditahan oleh dinding bejana tekan, dengan luas irisan $\left(\mathrm{A}_{2}\right)$, sebagaiman persamaan 7 .

$\mathrm{A}_{2}=\frac{\pi}{4}\left(4 \cdot \mathrm{D} \cdot \mathrm{t}+4 \mathrm{t}^{2}\right)$

Dengan terjadinya tegangan didalam dinding bejana tekan sebesar $\sigma$ t, sebagaimana persamaan 8 .

$\sigma \mathrm{t}=\frac{\mathrm{P}}{\mathrm{A}_{2}}$

Berdasarkan proses perhitungan analisa gaya bejana didapatkan data hasil perhitungan sebagaimana tabel 3 berikut

Tabel 3. Data hasil perhitungan

\begin{tabular}{ccc}
\hline Variabel Perhitungan & $\begin{array}{c}\text { Hasil } \\
(\mathbf{N} / \mathbf{m m} 2)\end{array}$ & Ketentuan \\
\hline$\sigma \mathrm{t}_{1}$ & 33.6 & $\sigma_{\mathrm{t} \text { ijin }} \geq \sigma_{\mathrm{t}}$ \\
$\sigma \mathrm{t}_{2}$ & 17.5 & $\sigma_{\mathrm{t} \mathrm{ijin}} \geq \sigma_{\mathrm{t}}$ \\
\hline
\end{tabular}

4. Analisa tegangan terhadap bejana (tegangan longitudinal dan circumferential)

Tegangan arah memanjang (longitudinal) yang terjadi di dalam bejana dapat dihitung menggunakan persamaan 9 berikut :

$\mathrm{S}_{1 \sigma}=\frac{\mathrm{p} \cdot \mathrm{D}}{4 \mathrm{t}}$

Sedangkan, tegangan arah melingkar (circumferential) yang terjadi di dalam bejana dapat dihitung menggunakan persamaan 10 berikut :

$\mathrm{S}_{2 \sigma}=\frac{\mathrm{p} \cdot \mathrm{D}}{2 \mathrm{t}}$

Berdasarkan proses perhitungan analisa tegangan bejana didapatkan data hasil perhitungan sebagaimana tabel 4 berikut :

Tabel 4. Data hasil perhitungan

\begin{tabular}{ccc}
\hline Variabel Perhitungan & $\begin{array}{c}\text { Hasil } \\
(\mathbf{N} / \mathbf{m m} \mathbf{2})\end{array}$ & Ketentuan \\
\hline $\mathrm{S}_{1 \sigma}$ & 17.8 & $\sigma_{\mathrm{t} \text { ijin }} \geq \mathrm{S}_{1 \sigma}$ \\
$\mathrm{S}_{2 \sigma}$ & 35.6 & $\sigma_{\mathrm{t} \text { ijn }} \geq \mathrm{S}_{2 \sigma}$ \\
\hline
\end{tabular}

Berdasarkan hasil data dari masing - masing perhitungan, bejana tekan dinyatakan aman untuk bekerja pada spesifikasi yang telah ditentukan. 


\subsection{Perhitungan heat exchanger}

Perhitungan heat exchanger ini bertujuan untuk menentukan panjang pipa sebagai heat transfer pada siklus destilasi bioethanol. Perencanaan yang dilakukan pada heat exchanger adalah dengan menentukan nilai LMTD, nilai kalor, reynolds number, nuzelt number, nilai koefisien konveksi perpindahan panas, luas permukaan, panjang pipa, jumlah pitch, jarak antar pitch, dan sudut helical [10].

Jenis aliran yang digunakan dalam perencanaan heat exchanger ini adalah menggunakan jenis aliran counter-curent flow dimana untuk temperatur masuk uap $\left(\mathrm{T}_{\mathrm{hi}}\right) 100^{\circ} \mathrm{C}$, temperatur keluar uap $\left(\mathrm{T}_{\mathrm{ho}}\right) 78^{\circ} \mathrm{C}$, temperatur masuk air pendingin $\left(\mathrm{T}_{\mathrm{ci}}\right) 65^{\circ} \mathrm{C}$, dan temperatur keluar air pendingin $\left(\mathrm{T}_{\mathrm{co}}\right) 86^{\circ} \mathrm{C}$.

Persamaan perhitungan untuk harga beda log-mean temperature different (LMTD) dihitung menggnakan persamaan 11 sebagai berikut :

$\Delta \mathrm{T}_{\mathrm{LMTD}}=\frac{\Delta \mathrm{T}_{1}-\Delta \mathrm{T}_{2}}{\ln \left(\frac{\Delta \mathrm{T}_{1}}{\Delta \mathrm{T}_{2}}\right)}$

Dimana untuk $\Delta \mathrm{T}_{1}$ adalah beda temperatur masuk uap $\left(\mathrm{T}_{\mathrm{hi}}\right)$ dan $\Delta \mathrm{T}_{2}$ adalah temperatur keluar air pendingin $\left(\mathrm{T}_{\mathrm{co}}\right)$. Untuk nilai faktor koreksi $(\mathrm{Fc})$, ditentukan menggunakan persamaan 12 berikut :

$F c=\frac{\sqrt{R^{2}+1} \cdot(P+1)}{(R+1) \cdot \ln P / R}$

Dimana untuk (P) adalah laju kapasitas energi panas dan (R) adalah efektivitas temperatur fluida pendingin. Sehingga nilai log-mean temperature different berdasarkan faktor koreksi $(\mathrm{Fc})$ persamaan 13,

$\Delta \mathrm{T}_{\mathrm{m}}=\mathrm{Fc} \cdot \Delta \mathrm{T}_{\mathrm{LMTD}}$

Sedangkan untuk nilai kalor $(\mathrm{Q})$ ditentukan berdasarkan perkalian antara massa uap $\left(\mathrm{m}_{\mathrm{uap}}\right)$, panas jenis $(\mathrm{Cp})$ dan selisih temperatur $(\Delta \mathrm{T})$, sebagaimana persamaan 14 .

$\mathrm{Q}=\mathrm{m}_{\text {uap }} \cdot \mathrm{Cp} \cdot \Delta \mathrm{T}$

Dimana untuk nilai selisih antara temperatur masuk uap $\left(\mathrm{T}_{\mathrm{hi}}\right)$ dan temperatur keluar uap $\left(\mathrm{T}_{\text {ho }}\right)$.Untuk mengetahui aliran yang terbentuk pada proses heat exchanger, persamaan 15 perhitungan yang digunakan adalah sebagai berikut :

$\operatorname{Re}=\frac{\rho \cdot \mathrm{v} \cdot \mathrm{d}}{\mu}$

(Re) diartikan sebagai reynold number, $(\rho)$ adalah rapat massa, (v) adalah laju aliran fluida, (d) adalah diameter dalam pipa, dan $(\mu)$ adalah nilai koefisien gesek.

Nilai nuzelt number $(\mathrm{Nu})$ ditentukan berdasarkan perkalian antara dean number $(\mathrm{De})$ dan prandtl number (Pr). Sebagaimana persamaan 16.

$\mathrm{Nu}=2,08 \cdot \mathrm{De}^{0,2} \cdot \operatorname{Pr}^{0,28}$ 
Untuk menentukan nilai koefisien perpindahan panas (h) dapat dihitung menggunakan persamaan 17 sebagai berikut :

$\mathrm{h}=\mathrm{Nu} \frac{\mathrm{k}}{\mathrm{d}}$

Dimana (k) adalah nilai konduktivitas bahan. Sehingga total perpindahan panas (Uo) dihitung menggunakan persamaan 18 berikut :

$\mathrm{U}_{\mathrm{o}}=\frac{1}{\mathrm{~h}_{\mathrm{i}}}+\mathrm{Rfi}+\frac{\mathrm{t}}{\mathrm{k}}+\frac{1}{\mathrm{~h}_{\mathrm{o}}}$

Nilai (t) merupakan tebal bahan, dan Rfi adalah nilai resistance of fouling factor. Berdasarkan persamaan 19 perhitungan yang telah ditentukan, maka luas permukaan pipa (A) adalah,

$\mathrm{A}=\frac{\mathrm{Q}}{\text { Uo.F. } \Delta \mathrm{T}_{\mathrm{m}}}$

Sehingga diperoleh panjang pipa heat exchanger (L) yang akan digunakan pada proses pembuatan sebagaimana persamaan 20 berikut :

$\mathrm{L}=\frac{\mathrm{A}}{\pi \cdot \mathrm{d}}$

Dengan nilai panjang yang telah diperoleh maka untuk jumlah lingkar pitch (n) pada pipa heat exchanger sebagaiman persamaan 21.

$\mathrm{n}=\frac{\text { Panjang Pipa }(\mathrm{mm})}{\text { Panjang } 1 \text { pitch }(\mathrm{mm})}$

Maka, jarak pitch dihitung menggunakan persamaan 22 berikut :

Jarak Pitch $=\frac{\text { Tinggi Coil }}{\text { Jml Pitch }}$

Untuk sudut helical $(\mathrm{H})$ pada perencanaan coil heat exchanger ditentukan menggunakan persamaan 23 berikut.

$$
\mathrm{H}=\mathrm{R}\left(\theta-\theta_{\text {in }}+2 \pi \mathrm{n}\right) \tan \theta
$$

(R) adalah harga radius, sudut $(\Theta)$ memiliki range antara $0-2 \pi$, jika pada bagian inlet sebagai bagian bawah coil, maka sudutnya adalah $\left(\Theta_{\text {in }}\right)$, dan jumlah belokan adalah (n).

Berdasarkan data hasil perhitungan heat exchanger dari menara refluks pada destilator bioethanol, maka dapat disimpulkan data perhitungan sebagaimana tabel 5 berikut 
Tabel 5. Data hasil perhitungan

\begin{tabular}{cc}
\hline Variabel Perhitungan & Hasil Perhitungan \\
LMTD & $58.05^{\circ} \mathrm{C}$ \\
Kalor (Q) & $0.007253 \mathrm{~kW}$ \\
Reynold Number (Re) & 1552.85 \\
Nuzelt Number (Nu) & 8.23 \\
Total Perpindahan Panas (Uo) & $1.827 \times 10-4 \mathrm{~W}^{2} / \mathrm{C}$ \\
Luas Permukaan Pipa (A) & $0.16 \mathrm{~m}^{2}$ \\
Panjang Pipa (L) & $3 \mathrm{~m}$ \\
Jumlah Lingkar Pitch (N) & 10 \\
Jarak Pitch & $40 \mathrm{~mm}$ \\
Sudut Helical (H) & $7.4^{\circ}$ \\
\hline
\end{tabular}

Berdasarkan proses perhitungan perancangan diperoleh spesifikasi yang akan digunakan pada proses pembuatan menara refluks, meliputi :

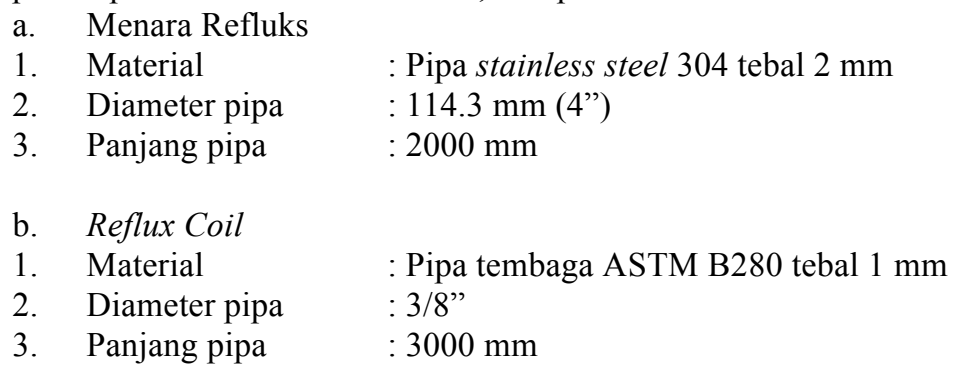

\subsection{Simulasi Design}

Proses desain pada umumnya memperhitungkan aspek fungsi, estetika, dan berbagai macam aspek lainnya dengan sumber data yang didapatkan dari riset, pemikiran, maupun dari desain yang sudah ada sebelumnya. Proses permodelan yang dilakukan pada menara refluks ini adalah menggunakan analisis simulasi CFD (Computational Fluid Dynamics). Dimana proses simulasi design yang dilakukan bertujuan untuk megetahui fase - fase aliran fluida yang terbentuk pada design menara refluks. Dimana proses simulasi ini digunakan sebagai proses perencanaan terhadap design dari menara refluks pada destilator.

Proses simulasi permodelan menggunakan analisis CFD (Computational Fluid Dynamics), akan diperoleh data berupa presentase temperatur yang akan digunakan sebagai proses perencanaan heat exchanger pada menara refluks. Presentase yang akan dianalisa pada menara reluks adalah jenis aliran $\mathrm{H}_{2} \mathrm{O}$ fase uap dan aliran $\mathrm{H}_{2} \mathrm{O}$ fase cair. Berikut pada gambar 2, merupakan hasil permodelan terhadap aliran $\mathrm{H}_{2} \mathrm{O}$ fase uap yang terjadi didalam menara refluks. 


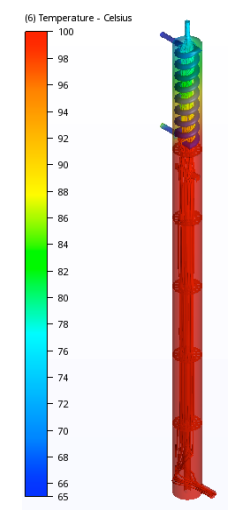

\section{Gambar 2. Simulasi Aliran $\mathrm{H}_{2} \mathrm{O}$ Fase Uap}

Berdasarkan hasil simulasi, diperoleh data berupa penurunan temperatur $\mathrm{H}_{2} \mathrm{O}$ fase uap sebagaimana gambar 3 berikut.

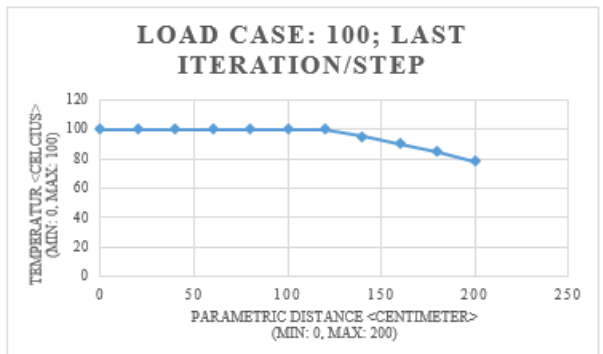

\section{Gambar 3. Grafik Simulasi $\mathrm{H}_{2} \mathrm{O}$ Fase Uap}

Dengan data input berupa temperatur masuk uap $\left(\mathrm{T}_{\mathrm{hi}}\right)$ sebesar $100^{\circ} \mathrm{C}$, dengan tekanan asumsi sebesar 1 bar dan laju aliran uap sebesar $1.5 \mathrm{~m} / \mathrm{s}$, terjadi penurunan temperatur secara bertahap pada siklus aliran yang terjadi. Penurunan akhir terhadap temperatur keluar uap $\left(\mathrm{T}_{\text {ho }}\right)$ adalah sebesar $78^{\circ} \mathrm{C}$.

Sedangkan pada gambar 4 berikut hasil simulasi pada siklus aliran yang terjadi pada $\mathrm{H}_{2} \mathrm{O}$ fase cair di dalam menara refluks.

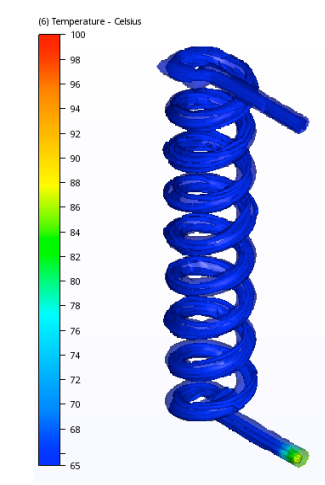

\section{Gambar 4. Simulasi Aliran $\mathrm{H}_{2} \mathrm{O}$ Fase Cair}

Berdasarkan hasil simulasi, diperoleh data berupa penurunan temperatur $\mathrm{H}_{2} \mathrm{O}$ fase cair sebagaimana gambar 5 berikut. 


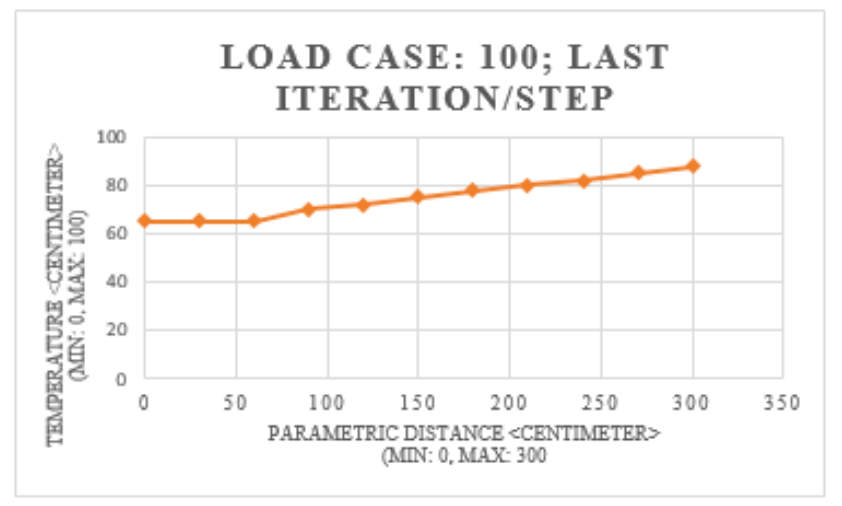

Gambar 5. Grafik Simulasi $\mathrm{H}_{2} \mathrm{O}$ Fase Cair

Dengan data input berupa temperatur masuk uap $\left(\mathrm{T}_{\mathrm{ci}}\right)$ sebesar $65^{\circ} \mathrm{C}$, dengan laju aliran air sebesar $30 \mathrm{l} / \mathrm{min}$, terjadi penurunan temperatur secara bertahap pada siklus aliran yang terjadi. Penurunan akhir terhadap temperatur keluar uap $\left(\mathrm{T}_{\mathrm{co}}\right)$ adalah sebesar $88^{\circ} \mathrm{C}$.

\subsection{Proses pengujian}

Proses pengujian pada menara refluks dilakukan untuk mengatahui perencanaan heat exchanger yang telah dilakukan perhitungan secara matematis sebelumnya. Berikut pada tabel 6 merupakan tabel hasil pengujian lapangan pada menara refluks.

Tabel 6. Hasil pengujian menara refluks

\begin{tabular}{cccc}
\hline \multirow{2}{*}{$\begin{array}{c}\text { Bahan Baku } \\
(\boldsymbol{l})\end{array}$} & $\begin{array}{c}\text { Temp. In Refluks } \\
\left({ }^{\mathbf{0}} \mathbf{C}\right)\end{array}$ & $\begin{array}{c}\text { Rencana } \\
\left({ }^{\mathbf{0}} \mathbf{C}\right)\end{array}$ & $\begin{array}{c}\text { Hasil } \\
\left({ }^{\mathbf{0}} \mathbf{C}\right)\end{array}$ \\
\cline { 3 - 4 } & & 78 & 77 \\
50 & 100 & 78 & 78 \\
50 & 100 & 78 & 78 \\
\hline
\end{tabular}

Berdasarkan data pengujian yang diperoleh, maka dapat disimpulkan temperatur keluar menara rata - rata adalah sebagai berikut:

$\overline{\mathrm{x}}=\frac{\Sigma}{\mathrm{n}}=\frac{(77+78+78)^{\circ} \mathrm{C}}{3}=77,67^{\circ} \mathrm{C}$

Sedangkan tabel hasil pengujian keseluruhan terhadap mesin destilator bioethanol yang telah dibuat adalah sebagaimana tabel 7 berikut :

Tabel 7. Hasil pengujian destilator bioethanol

\begin{tabular}{|c|c|c|c|}
\hline \multirow[b]{2}{*}{$\begin{array}{c}\text { Lama Fermentasi } \\
\text { (Hari) }\end{array}$} & \multirow[b]{2}{*}{$\begin{array}{c}\text { Temp. Refluks } \\
\left({ }^{\circ} \mathrm{C}\right)\end{array}$} & \multicolumn{2}{|c|}{ Pengujian Bioethanol } \\
\hline & & $\begin{array}{c}\text { Hasil } \\
(l)\end{array}$ & $\begin{array}{c}\text { Kadar } \\
(\%)\end{array}$ \\
\hline 7 & 78 & 2,35 & 91 \\
\hline
\end{tabular}


Berdasarkan hasil pengujian pada destilator bioethanol dengan lama fermentasi 7 hari pada tetes tebu, didapatkan hasil etanol 2,35 liter dengan tingkat kemurnian pada $91 \%$.

\section{KESIMPULAN}

Pada penelitian terkait rancang bangun menara refluks pada destilator bioethanol kapasitas 5 liter/jam berskala UMKM, dapat ditarik kesimpulan sebagai berikut :

1. Telah dirancang menara refluks berbahan stainless steel tipe 304 dengan dimensi shell berdiameter $114 \mathrm{~mm}$, ketinggian $2000 \mathrm{~mm}$ dan tebal $2 \mathrm{~mm}$. Telah dirancang pula reflux coil berbahan tembaga ASTM B280 dengan total ketinggian coil $400 \mathrm{~mm}$, dengan jumlah lingkar 10 buah dan jarak antar pitch $40 \mathrm{~mm}$.

2. Telah dibuat menara refluks pada destilator bioethanol dengan komponen - komponen yang dibuat meliputi, flange, sekat zeolit, reflux coil, pipa refluks dan pipa menara pendingin.

3. Berdasarkan pengujian lapangan pada komponen mesin destilator bioethanol yaitu menara refluks didapatkan data temperatur masuk uap $\left(\mathrm{T}_{\mathrm{hi}}\right)$ sebesar $100^{\circ} \mathrm{C}$ dan temperatur keluar uap $\left(\mathrm{T}_{\text {ci }}\right)$ rata - rata sebesar $77.67^{\circ} \mathrm{C}$ dalam waktu 1 jam beroperasi.

4. Berdasarkan pengujian lapangan pada destilator bioethanol yang dibuat telah di hasilkan bioethanol sebesar 2,35 liter dalam waktu 1 jam dengan kadar kemurnian $91 \%$.

\section{DAFTAR PUSTAKA}

[1] Hambali, Erliza, and S. Mujdalipah, Teknologi Bioenergi. Jakarta: Agromedia Edition, 2007.

[2] M. Balat, H. Balat, and C. Ot, "Progress in Bioethanol Processing," Energy Combust. Sci., vol. 34, pp. 551-552, 2007.

[3] M. Afriani, Gusnedi, and Ratnawulan, "Pengaruh Tinggi Kolom Pada Distilasi Terhadap Kadarbioetanol Dari Tebu ( Saccharum Officinarum )," PILLAR Phys., vol. 5, p. 28, 2015.

[4] M. Hasanah, N. Andriani, and Noprizon, "Perbandingan Aktivitas Antioksidan Ekstrak Etanol Daun Kersen ( Muntingia calabura L .) Hasil Ekstraksi Maserasi Dan Refluks," SCIENTIA, vol. 6, no. 2, p. 87, 2016.

[5] J. . Harbone, Metode Fitokimia,Penuntun Cara Modern Menganalisa Tumbuhan, Diterjemahkan Oleh K. Padmawinata. Bandung: ITB Press, 1987.

[6] S. Ihsan, "Perencanaan dan Analisa Perhitungan Jumlah Tube dan Diameter Shell pada Kondensor Berpendingin Air pada Sistem Refrigerasi NH 3," J. Teknol. PROSES DAN Inov. Ind., vol. 2, no. 1, pp. 14-15, 2017.

[7] R. Winarso, B. S. Nugraha, A. Muttaqin, and N. Rofiudin, "Pengembangan Alat Destilator Bioetanol Sebagai Bahan Bakar Alternatif," Pros. SNST Univ. Wahid Hasyim Semarang, pp. 47-48, 2014.

[8] M. Ichsan, B. S. Nugraha, and R. Winarso, "Analisa Pengaruh Lama Fermentasi Terhadap Kadar Bioetanol Pada Mesin Destilator Model Reflux,” J. SIMETRIS, vol. 6, no. 2, p. 318, 2015.

[9] Djokosetyardjo, KETEL UAP. Jakarta: Pradnya Paramita, 2003.

[10] J. P. Holman, HEAT TRANSFER. Singapore: McGraw-Hill.Inc, 1986. 